\title{
Rank, M., Eppard, L., and Bullock, H. (2021) Poorly Understood: What America Gets Wrong About Poverty. Oxford University Press.
}

\author{
Review by Ryan Pettengill
}

Arguably no politician weaponized the misunderstanding surrounding poverty quite as effectively as Ronald Reagan. In a 1976 campaign speech in Asheville, North Carolina, Reagan invoked widely-held yet mostly false assumptions regarding persons benefiting from public assistance. Using the racially-charged term 'welfare queen,' he implied this individual was a product of urban America, had several children (many of whom were from different fathers), and committed fraud to unjustly claim more than her fair share of public assistance. In essence, these individuals were not only celebrating their poverty but profiting from it. In the process, Reagan distorted an already misunderstood concept - poverty in America. Mark Robert Rank, Lawrence M. Eppard, and Heather E. Bullock challenge these misconceptions in Poorly Understood. In the process, the authors shed light on who the poor are, why poverty exists, what causes poverty, the social safety net designed to address poverty, how institutionalized inequality (based on race, sex, class, etc.) oftentimes leads to poverty, as well as what might be done to substantially reduce the level of poverty in the United States.

Rank, et al. begin their analysis by determining who the poor are, where they live, and how long they tend to experience poverty. The authors believe that a central driver of the myths surrounding poverty is an 'us' versus 'them' understanding of the issue (p. 7). Many Americans believe that the poor are concentrated in cities, hold few professional skills, and will remain mired in their condition indefinitely. In other words, poor people are outliers in American life. But the authors find that poverty is much more pervasive than Americans like to believe. Statistically speaking, most Americans will experience poverty at some point in their lives (p. 10). Rank, et al. find that the poor can be found in virtually any location across the country. In fact, they point out that in terms of sheer numbers, suburbia now holds the dubious honor of housing the largest conglomeration of poor people. Although most of these individuals experience poverty only in brief, fluid spells, poverty is anything but an outlier in American life. Indeed, economic 'insecurity is in fact something that happens to most of us' (p. 27).

With respect to why poverty exists in the United States, Rand, et al. point to the lack of availability of jobs with which individuals can support themselves or their families. While the common assumption is that poor people are lazy or lack adequate skills to compete in a modern job market, the authors insist that the American economy has produced an inordinate amount of low-paying jobs that leave workers economically insecure and vulnerable to the ebb and flow of the market. Complicating matters, policymakers - playing upon the myth that poverty is in many ways unavoidable - have successfully scaled back public welfare programs that have been effective in reducing poverty. According to the authors, this myth 'breeds apathy and an acceptance of the status quo' (p. 68). The authors reject the myth and claim that it 'is simply incorrect to argue that poverty cannot be substantially reduced' (p. 64). Pointing to President Lyndon Johnson's War on 
Poverty, they highlight a period in which the American government made a concerted effort to not only address poverty but also the underlying social circumstances that perpetuate it.

The tolerance of poverty, as the authors note, is not without social consequences. Specifically, childhood poverty results in the American taxpayer spending more money in the long run. The authors believe that the societal costs of poverty are the product of public policies that have favored the economic elite, namely through tax cuts for the wealthy. Rand, et al. believe that the persistence of poverty has much less to do with specific character flaws of the poor and much more to do with systemic inequality. This inequality results in 'a range of troubling societal conditions, including lower life expectancy, worse health conditions, reduced child well-being and academic performance, crime and incarceration, drug abuse, teenage birthrates, and lower levels of trust...' (p. 145).

Why, then, do Americans continue to cling to the status quo and accept poverty as an inevitable byproduct of free market capitalism? Rand, et al. believe poverty represents the 'American nightmare' (p. 164). The American dream is grounded in the concept of opportunities being endless in the United States, the assumption being that anyone willing to work hard and play by the rules has the capability to rise in this world. So, this being the case, there must be something wrong with the individual who is mired in poverty - they have not worked hard enough, made poor decisions, or acquired enough skills. As Rand, et al. point out, to 'acknowledge that poverty is simply endemic to America as a whole is to challenge the very core of the nation's ideals and creed' (p. 165). It is easier to simply write off the poor as outliers and exceptions to the rule.

One key challenge in making sense of the late twentieth and early twenty-first century economy is balancing the concept of new opportunities with new vulnerabilities. Indeed, the economy did add millions of jobs but it did so in the emerging service-based sectors, which tended to pay low wages and offered few benefits. With respect to poverty, most teachers, scholars, and activists emphasize downturns in the American economy and how they translated into unemployment, which then translated into poverty. As historians like David Kennedy note, throughout the Great Depression, hundreds of thousands of workers lost their jobs on a weekly basis. The calamities that resulted from this unemployment ran the gamut: malnutrition, homelessness, an assortment of health challenges, etc. In essence, being unemployed was an important part of being 'poor.' As Poorly Understood observes, poverty had changed by the late twentieth century. Now it was possible to be poor yet still employed. Saul Alinsky would describe these individuals as 'have some, want more.' In Rules for Radicals, Alinsky stresses how important it is to reach out to individuals like these and bring them into the broader fight for economic justice, lest they become prey to the Wallaces or Nixons of the world. To that end, the current political backdrop of Trumpism and the impulse to explain away large, complex concepts in overly simple, bite-sized anecdotes makes Poorly Understood even more timely. Even though misinformation presents a powerful challenge, the authors believe that the twenty-first century offers a unique opportunity to 'reshape general perceptions to better align with the actual realities rather than the myths of poverty' (p. 180). They note the way the Me Too and Black Lives Matter movements have effectively used social media to fight against sexual harassment/assault and police brutality. They believe social media has the potential to spread awareness and call people to action with respect to standing up to injustice and poverty in America. 
A more thorough understanding of poverty helps bring agency to the American working class. In that respect, Poorly Understood makes a valuable contribution to working-class studies. Moreover, it is grounded in an interdisciplinary approach, making it relevant to academics from a wide range of backgrounds. Perhaps most important of all, Poorly Understood teases out the misconception that poverty is not a racial problem or a regional problem but an American problem, giving labor and social activists a launching pad from which to delve into a deeper conversation with those standing on the sidelines and stress the urgency of the matter when it comes to poverty in America.

\section{Reviewer Bio}

Ryan S. Pettengill teaches history at Collin College in Texas. He is a labor historian whose work focuses on the intersection of working-class activism and American radicalism throughout the twentieth century. His most recent book is entitled Communists and Community: Activism in Detroit's Labor Movement, 1941-1956. 